\title{
Legalised theft by deregistration
}

\author{
Herbert Roth*
}

This paper explores the history of deregistration provisions in industrial legislation and suggests how these provisions have been used in the past by governments as a weapon against recalcitrant unions.

\section{Introduction}

Question 36 of the Government's Green Paper asks: "Should employer and worker organisations be subject to suspension or dissolution, and if so, what criteria should determine the exercise of this power. and by whom should it be exercised?" (Industrial Relations, 1985. v.1 p.36). The reference, of course, is to the power of deregistration of a union. contained in the Industrial Relations Act, and the authors of the Green Paper comment in volume 2:

\footnotetext{
The present deregistration provisions are contrary to ILO Convention 87 because they vest the power to deregister with the Minister of Labour alone. and no avenue of appeal is provided ... It is to be noted that the power of deregistration is not of itself contrary to the Convention. Thus. if deregistration is to be retained in the legislation. a means of exercising the power needs to be found which is consistent with the Convention. An alternative is the maintenance of the present ministerial power with the right of judicial appeal superimposed. (Ibid. v.2 p.276).
}

The relevant article 4 of ILO Convention 87 (Convention concerning the Freedom of Association and Protection of the Right to Organise) reads: "Workers" and employers" organisations shall not be liable to be dissolved or suspended by administrative authority". and the authors of the Green Paper clearly think that by transferring the power of deregistration to a judicial authority, they would, in their own words. be "moving towards legislation which is, where reasonable, consistent with the Convention." (Ibid.) My view is that the current deregistration powers. whether by administrative or judicial authority, cannot be considered reasonable or equitable as long as they retain the clauses providing for the seizure of all assets of a deregistered union. and that these clauses should be deleted.

\section{Origins}

The power to deregister a union and cancel its award as a penalty for striking was first conferred on the Minister of Labour by the Industrial Conciliation and Arbitration Amendment Act of 1939. The immediate occasion was a strike by Auckland fertiliser workers: the bill was introduced in both Houses and passed on the same day ( $18 \mathrm{July}$ ), and the Minister deregistered the small Otahuhu Chemical Manure Workers Union 2 days later, on 20 July. Parliament was told, however, that the bill had been under consideration by the Government for a considerable time and that it was brought down only after consultation with the interested parties. (Parliamentary Debates, 18 July 1939, p.462). It was "just a small bill of two clauses". said the Hon. David Wilson, who introduced the bill in the Legislative Council, but the Hon. Tom Bloodworth, a former union secretary who had broken with the Labour Party, 
retorted that it was a very important bill, with far-reaching effects. which made possible "the undoing of trade unions in this country almost altogether." (Ibid. p.456). The question of a right of appeal against the Minister's decision was raised by an Opposition member. but Armstrong, a former Minister of Labour, ridiculed the idea: "Who is the appeal to go to?" he asked. "A Judge of the Supreme Court of the Court of Arbitration? This legislation is going to enable the Minister to act quickly, and time is the essence of the contract. If one is going to give the right of appeal against his decision it means that the stoppage can continue until the appeal is heard, which may be a month or six weeks afterwards." In any case. he argued somewhat unconvincingly. "the present Cabinet should be looked upon as the highest Court of Appeal in this country." (Ibid. p.476).

There was no suggestion then that deregistration implied the dissolution of the offending union. It merely deprived it of access to the Arbitration Court and the ability to obtain an award. "If they do not want the principles of arbitration to govern their conduct." said Webb. the Minister of Labour. "let them remain outside the protection of the Court. They cannot have it both ways." (Ibid. p.479). Deregistration gave the union the legal right to strike (within the limits set by the Labour Disputes Investigation Act) but it also gave the employer the right to employ non-union labour. since the compulsory membership provisions no longer applied. The Otahuhu Chemical Manure Workers Union did in fact continue to operate as an incorporated society under the Labour Disputer Investigation Act until 1959. when it reregistered under the Arbitration Act as the Northern Industrial District Chemical Fertiliser Workers Union.

The 1940 conference of the Federation of Labour adopted a remit from the New Zealand Waterside Workers Union (prophetic in view of what happened to that union in 1951) asking "that the recent amendment making provisions for the Minister to cancel the registration of unions be repealed," (Federation of Labour, 1940, p.11) but the Labour Government ignored whatever representations the Federation made and continued to use the power of deregistration on a number of occasions during the war. In November 1940. the Minister of Labour deregistered the Wellington Tobacco Workers' Union: in 1942, the Auckland Freezing Workers' Union; and in January 1944 the Auckland Drivers Union. The tobacco and freezing workers re-registered soon afterwards under new names, but the Auckland drivers did not gain reregistration until 1946.

A major confrontation came in 1949. during the Auckland carpenters strike, when McLagan, the Minister of Labour, deregistered the New Zealand Carpenters Union on 25 March within a 56-mile radius from the Auckland Central Post Office. Now, for the first time apparently, the question of seizing or freezing a deregistered union's funds was raised. There was a sizeable dissident group among the Auckland carpenters, who took steps to form a new union with the assistance of the master builders. A leader of this group urged McLagan to prevent the "dissipation" of the old union"s funds. That union of course used these funds to perpetuate the strike. which the Government and the employers were anxious to bring to an end. The Secretary of Labour sought the advice of the Solicitor-General. Herbert Evans, who. after consulting with Treasury and other officials, replied on the same day (12 April) as follows:

I have been unable to see how the Reserve Bank or any Department of the Government can take any step to prevent the persons who have authority under the Rules of the New Zealand Union to deal with the funds of the Branch, from withdrawing them from the branch banking account or from realising any assets which are not in the form of cash. The only kind of proceeding which could have the effect of preventing or delaying such dealings would be a proceeding by a financial member or financial members of the Auckland Branch of the New Zealand Union. claiming to have an interest in the property. alleging a fear that it may be applied by way of personal benefit to other members. and claiming a declaration that they may not lawfully be so applied and an injunction against such application. (Evans. 1949).

I do not know whether any branch member initiated such proceedings, but in May 1949 McLagan approved the registration of the breakaway Auckland Carpenters and Joiners and Joiners' Machinists Union. which functioned within the 56-mile radius. The old Auckland union continued to operate. but the compulsory membership clauses. fortified by an amendment to the Arbitration Act passed in October 1949, required all carpenters working in the city to join the new union. Unity was not restored until 1959. when the new Auckland union became again a branch of the national union. 
Deregistration

23

During the 1951 waterfront dispute, the now National Government used its powers of deregistration freely against no fewer than 6 unions: the New Zealand Watersides' Union. the Wellington Drivers' and Freezing Workers unions, the Portland and Golden Bay Cement Workers' Unions, and the Ohura Coal Miners union. The Government also proclaimed a state of emergency under the Public Safety Conservation Act of 1932 and, under this act, took powers by emergency regulations to seize the assets of each deregistered union and to appoint a receiver in the person of the Public Trustee. There was no question then that the Government was determined to destroy these unions by administrative action. The lengths to which it was prepared to go can be illustrated by the example of the Wellington Drivers Union.

When the drivers voted to refuse carrying goods handled by servicemen. Sullivan, the Minister of Labour. deregistered their union on 10 April. Two days later he approved registration of a breakaway Wellington (30-mile radius) union formed with the assistance of the master carriers. The old union then reregistered under the Trades Union Act. but Sullivan appointed the Public Trustee as receiver of the union's assets and invoked the emergency regulations to cancel the second registration. When the drivers secretary refused to hand over the union's property, he was arrested on 2 May, prosecuted. and fined $£ 50$.

Other union officials also refused to co-operate with the Public Trustee and suffered the consequences. The secretary of the Lyttelton branch and a trustee of the Auckland branch of the watersides' union were each fined $£ 50$ for failing to account for large sums withdrawn from the branch accounts at the beginning of the dispute. The secretary of the Wellington freezing workers' union was arrested and fined for non-cooperation, and in July the police raided the freezing workers' office and drilled open the safe. where they found nothing of consequence. Not until after the end of the dispute did the Auckland watersides' secretary supply the Public Trustee with a full statement, supported by receipts. of how $£ 4900$ had been spent for the benefit of his members.

By then, receivers throughout the country were holding a great variety of union assets: office equipment. motor vehicles, certificates of government stock, and even working clothes. The Government revoked the regulations under which this property had been seized on 26 July, 1951 when it lifted the state of emergency, but it took no steps to return the assets until November, when it introduced a Union Funds Distribution Bill, which passed through Parliament with the support of the Labour Opposition. The national watersides' union was still functioning, mainly thanks to financial assistance from Australian unions (the Auckland branch of the deregistered union did not disband until 1954), but the new legislation did not provide for restitution of the seized assets to their former owners. Instead it instructed the Public Trustee to realise the assets and to divide the proceeds in equal shares among the members of the each union. As an alternative, a meeting of union members could decide, by a majority of not less than 75 percent. to transfer the property to another registered union in the same industry and locality, ie. to whatever successor union had been registered during the dispute with the approval of the government. Members did not have the option of voting to return the property to its rightful owner, the deregistered union. The act also validated retrospectively the actions of the Public Trustee since the revocation of the emergency regulations 4 months earlier.

The ILO

The watersides' union, assisted by the World Federation of Trade Unions, lodged a complaint with the International Labour Organisation (ILO), Committee on Freedom of Association that the New Zealand Government had violated trade union rights during the waterfront dispute. One of the main items of complaint was that "the government took measures intended to bring about the dissolution of the union by deregistering the union and by seizing a sum of $£ 20000$ belonging to the trade union and the trade union archives." In its reply to the complaint, the New Zealand Government (on 11 December 1951) argued that the watersides union was deregistered on account of an illegal strike but was not dissolved, and that the Government had temporarily seized the union's funds in order to prevent them being utilised for the purposes of the strike.

Pressed by the ILO for further details, the Government replied in a second letter (of 25 February 1952), which the ILO Committee summarised in its report as follows: 


\begin{abstract}
The Government explains in its reply that the union funds were seized solely to prevent their use in furtherance of an unlawful strike. The unions concerned were allowed to draw on the funds for all lawful union purposes such as salaries of office staff, office expenses, etc. Following the revocation of the Emergency Regulations, the distribution of the funds seized was provided for by Act No. 20 of 1951. The text of this Act was attached to the reply. The Government emphasises that the Act provides for the equitable distribution of the funds affected in accordance with the wishes of the members of the unions concerned. The Act itself was passed after consultation with officers of the unions affected and with their concurrence in its provisions. It appears from a document attached to the reply that the funds of various unions whose registration was cancelled have been transferred to occupational organisations set up for the same purpose in the same localities. (ILO Committee. 1952).
\end{abstract}

It is extremely doubtful that the officers and members of the Auckland watersiders' branch gave their approval to the Union Funds Distribution Act, assuming that they were indeed consulted, but the ILO Committee accepted the New Zealand Government's explanations.

\title{
Deregistration revived
}

Another 10 years went by before the Government again used its deregistration powers, this time against 4 fertiliser workers' unions which were struck off the register in May 1962. Deregistration in this instance was a concession rather than a punishment, for the 4 unions had themselves applied to be deregistered so as to gain the right to operate under the Labour Disputes Investigation Act, and the Minister's action speeded up the process. One of the unions affected was the Norther Industrial District Chemical Fertiliser Workers Union, successor to the previously deregistered Otahuhu Chemical Manure Workers Union. It continued to operate as an incorporated society until 1974, when it reregistered under the Industrial Relations Act.

In November 1971. the Government deregistered the New Zealand Seamen's Union during a seamen's strike promoted by the union's fierce Auckland branch. which stood in opposition to the national leadership. Anticipating deregistration, the union sought to withdraw all funds from its central account with the ANZ Bank in Wellington but, according to the Prime Minister, Sir John Marshall, the amount in figures on the cheque was different from the value in words and exceeded the total held in the account. The bank refused to meet the cheque and, before a new cheque could be drawn, the union had been deregistered and the bank again refused to pay out. (Parliamentary Debates, 24 November 1971, p.4843).

The Prime Minister told Parliament:

A registered union is a body corporate and its separate legal entity is destroyed upon deregistration. Possibly the funds in law rest with the members of the union, but there is the problem as to who has the authority to operate on the accounts or distribute the funds. Both the Solicitor-General. who has been consulted, and the solicitors for the Australia and New Zealand Bank are agreed that the officials of the deregistered union have now no legal authority to operate on the central account. (Ibid., 25 November 1971, p.4904).

It will be seen that these legal opinions are in direct contradiction to the SolicitorGeneral's opinion in 1949 quoted earlier. They also contradict the Government's statement to the ILO in 1952, that deregistration did not involve dissolution, or the Secretary of Labour's, Noel Woods, opinion, stated in a booklet published in 1968, that "deregistration merely cancels the registration under the IC \& A Act and does not dissolve or suspend the existence of the union". (Woods, 1968, p.44).

The national officials of the Seamen's Union did not apparently challenge the bank's interpretation of their powers, but the Government stepped in, still in November 1971. and introduced a Seamen's Union Funds Bill. This bill, which passed through Parliament with the support of the Labour Party, appointed the Public Trustee as manager of the funds and assets of the old union, to be held in trust and administered until they were vested in a new union. There was no provision for the funds to be divided among the members. The Seamen's Union was reregistered in February 1972 under its old name and with all its existing members, but with new rules which strengthened the executive's power over the branches, and the Minister of Labour issued a declaration, published in the Gazette, that the assets under the control of the Public Trustee were now vested in the new union. 
The arrangements for the disposal of the seamen's funds apparently suited all the parties concerned, with the possible exception of the activists in the Auckland branch, but unfortunately they then became a precedent for similar provisions in subsequent legislation. The Federation of Labour and the Employers Federation were then holding discussions on a major revision of our industrial laws. They reached agreement on most points, with the significant exception of the question of penalties for what was called politely "unjustified industrial action". The National Government was left to fill in the gaps, and in the Industrial Relations Bill which it put before Parliament in October 1972, it included new clauses which stipulated that on deregistration of a union. all its assets were to be vested in the Public Trustee until their transfer to a successor union or, if no such union was formed within 6 months, their distribution among the union's members.

In his introductory speech Thomson, the Minister of Labour, did not draw attention to these new clauses, but a much fuller statement published by the Government claimed that "because the union is a body corporate, special provision must be made for the disposal of its assets" after deregistration (Industrial Relations Bill, 1972, p.20). The explanatory note attached to the bill made clear the origin of this innovation: the new clauses, it said, "are adapted from the Seamen's Union Funds Act 1971."

Parliament referred the bill to its Labour Committee where Woods, now retired from the Labour Department, was one of the few witnesses to protest strongly against the iniquity of the seizure of assets clauses. He wrote afterwards (repeating his 1968 argument):

\begin{abstract}
Under the previous provisions the deregistration of a union did not dissolve it. It merely stripped the union of the benefits of registration.... and cancelled the application of any award or industrial agreement to its members. It was thus reduced to a free-running position where it might survive given adequate reformation or continuing solidarity amongst its members and the support of the trade union movement in keeping the ring clear.
\end{abstract}

Seizure of assets however was, in Wood's words, a "very radical change in the legislation which allows a union to be dissolved by the government of the day, and allows it to be replaced only by a union which that government approves." This, he wrote "is completely contrary to the concept of freedom of association and the right to organise. It negates one of the foundation principles of trade unionism and it flies in the face of an international convention ratified by more than half the countries of the world," i.e. the ILO Convention 87 quoted earlier. (Woods, 1974, pp.31-32).

\title{
Labour in power
}

The Labour Government, formed after the election victory of 1972, made significant changes to the Industrial Relations Bill, but it retained the deregistration and seizure of assets clauses. The bill was passed in 1973 and the new legislation came into force in 1974. Woods commented sadly: "That the New Zealand trade union movement remained quiescent at the enactment of such provisions is astonishing but remains unexplained." (Ibid., p.33).

The Labour Government invoked the deregistration provisions only once, in July 1975. against members of the Auckland Boilermakers' Union employed on the construction of the No. 3 paper machine at the Tasman mill at Kawerau. Only 43 workers were affected and the question of seizure of assets never arose. The National Government, which returned to power later that year, also took action against boilermakers by deregistering their Wellington union in September 1976. This time the Public Trustee stepped in but his efforts, according to press reports, caused "a bit of a laugh" for the union owned no car, its office was part of the Wellington Trades Hall, and its bank account was low at the best of times. (Auckland Star, 9 October 1976). The Wellington boilermakers formed themselves into an incorporated society which continues to operate to the present day under the umbrella of the Federation of Labour and the Wellington Trades Council, which conducts negotiations on their behalf.

\section{Seizure of assets}

The justification for the seizure of assets is based on Marshall's view in 1971 that deregistration deprives a registered union of its legal existence. Dissolution by administrative 
action is, however, contrary to the ILO Convention 87, and the Green Paper seeks a way out by transferring the power of deregistration to a judicial authority. It does not even raise the question of seizure of assets, which magnifies the effect of deregistration and makes dissolution a virtual certainty, even though the small and tight Wellington boilermakers' union was able to survive the ordeal. The seizure of assets is one of the most objectionable features of our industrial legislation, and by retracing the history of these clauses I have shown how unfairly this weapon has been used in the past and what unfortunate precedents have been set. How far a malevolent government will travel along this road when it seeks to suppress a recalcitrant union, can be seen from one final example.

In 1979, the National Government was at loggerheads with the Public Service Association (PSA) and threatened to withdraw recognition from the PSA. This would have made life difficult but not impossible for the Association. Other state unions in the railways and post office had survived lengthy periods when the employing authorities refused to talk to them and, in the case of the Post Office Union, also refused its officials access to government premises and banned the circulation of its journal. However, when the Government introduced a Public Service Association Withdrawal of Recognition Bill in June 1979, it not only gave the Minister of State Services the power to withdraw the recognition of the Association as a State service organisation, but it also provided that, in case of derecognition. all assets of the PSA were to be vested in the Public Trustee, to be transferred to any new service organisation the Minister might recognise within 6 months. No explanation for this clause was put forward, except that it paralleled the deregistration provisions in the Industrial Relations Act. "If the Government does it, it will be as with the Wellington boilermakers," said Prime Minister Muldoon. (Parliamentary Debates, 22 June 1979, p.1020). The Government did not proceed with this bill but in 1983, in another clash with the PSA, it again introduced a derecognition bill with similar provisions, though this too was soon withdrawn.

If the justification for seizure in the case of deregistered industrial unions was that they had lost their corporate existence, what possible justification was there in the case of the PSA. which was not registered under any industrial legislation but was an incorporated society with a voluntary membership, and retained this legal status whether officially recognised or not? Yet the National Government twice introduced legislation to seize assets built up over more than 60 years and amounting to millions of dollars, and to transfer them to a new society more to its liking. "The last time such a measure was passed against a voluntary union of state servants was in 1933, in Germany," said the then Leader of the Opposition. David Lange. (Ibid., 21 October 1983, p.3252). It recalled the forcible transfer of all assets of the German trade unions to the Nazi Labour Front.

\section{References}

Evans, H (1949) Letter to the Secreary of Labour. 12 April. (Typescript).

Federation of Labour (1940) Minutes of third annual conference Wellington.

ILO Committee on Freedom of Association (1952) Case No. 21. (Typescript)

Industrial relations : a framework for review (1952) Wellington, Government Printer.

Industrial Relations Bill : government statement on the introduction of the Industrial Relations Bill into the House of Representatives, October 1972 (1972) Wellington, Government Printer.

Woods. N S (1968) Report on industrial relations legislation Wellington, Department of Labour. Woods, N S (1974) The Industrial Relations Act, 1973 : a study of the legislation Wellington,

Victoria University of Wellington Industrial Relations Centre. 